\section{NICE criteria for the use of cholinesterase inhibitors}

Simpson et al (Psychiatric Bulletin, November 2005, 29, 410-412) conclude from their naturalistic audit of the National Institute for Clinical Excellence (NICE) criteria for the treatment of Alzheimer's disease with cholinesterase inhibitors that 'the withdrawal of medication in line with NICE guidance is poor clinical practice and likely to have adverse outcomes in a large proportion of cases'.

Without a proper control group these conclusions are hard to support. It is possible that there may have been a greater deterioration in the group of 25 patients whose Mini-Mental State
Examination score fell below 12 had cholinesterase inhibitors not been withdrawn. We cannot speculate that this group would have had better outcomes if they had continued on the medication.

A useful quote which aids the understanding of audits is 'Research is concerned with discovering the right thing to do; audit with ensuring that it is done' (Smith, 1992). Good published clinical audit projects can inform others on best methods and be used as comparators for other clinical audit work (Talbot et al, 1997). The value of the naturalistic audit by Simpson et al lies in informing others about a possible discontinuation syndrome off cholinesterase inhibitors, but it would be interesting to compare their results with other similar audits involving withdrawal of medications according to NICE guidance. However, to discover the right thing to do and to validate their conclusions, only a well conducted randomised controlled withdrawal study would suffice.

SMITH, R. (1992) Audit and research. BMJ, 305 905-906.

TALBOT, D., REYNOLDS, D. J. M., STONE, P. G., et al (1997) Local research ethics committees. BMJ, 315, 1464.

AndrewTeodorczuk Specialist Registrar in Old Age Psychiatry, Foundry House, Old Age Psychiatry Service, Bedlington, Northumberland, e-mail: Andrew.Teodorczuk@newcastle.ac.uk

\section{the college}

\section{Amendments to College Bye-Laws and Regulations, 2005}

The work of the Scoping Group on the College's Constitution came to fruition in 2005 when amendments to the College's Bye-Laws and Regulations were approved by the College's Council, the AGM and by the Privy Council.

Key changes are summarised below.

\section{Committee structure}

Council and the Executive and Finance Committee will be replaced by a new streamlined Central Executive Committee (CEC) which will comprise 39 full members and will meet eight times a year. This rationalisation is aimed at increasing efficiency of College processes.

(The patient and carer representatives and the Affiliate will be ordinary members with full voting rights on the Committee, but will not have trustee status.)

(Full) Membership will comprise:

- Honorary Officers

- Chairs of Faculties and Sections

- Chairs of Divisions

- Four elected members (of whom not more than two may be Fellows)

- Chair of the PsychiatricTrainees' Committee

- One Affiliate nominated by the Affiliates and SAS (Staff and Associate Specialist) Members' Committee

- One patient and one carer representative nominated by the Patients' and Carers' Committee to join CEC and co-chair the Patients' and Carers' Committee

- Chair of the Special Committee on Professional Governance and Ethics (SCPGE)

- Directors of Conferences, Internationa Affairs and Public Education.
All members will serve a 5-year term of office (including Directors who will remain on the CEC for the duration of their offices).

Some changes are being made to the Standing and Special Committees.

The Court of Electors will become the Education, Training and Standards Committee (ETSC) to reflect its modern role and better describe its functions. The ETSC will be a sub-committee of the CEC. The ETSC will have authority to administer termination and disciplinary procedures.

(The remit is otherwise the same as that of the Court of Electors.) Membership will comprise the Dean (Chair), President, Registrar, Associate Deans, Chief Examiner, Director of Continuing Professional Development, Director of International Affairs, Director of Conferences, one Member elected by each Division, two post-Membership Psychiatric Trainees.

Changes to the committee structure will be introduced in October 2006 and details will be published on the College website.

\section{Equality and diversity}

The College was named in the Race Relations (Amendment) Act 2000 as a public authority with a 'General Duty'. The 'General Duty' requires specified organisations to 'eliminate unlawful racial discrimination, promote equality of opportunity, and promote good relations between persons of different racia groups'. In accordance with this requirement, and in keeping with the College's proactive race relations strategy, it was agreed to introduce several amendments, including additions to the Declaration made by new Members. This now requires Members to pledge to practise in accordance with the recently revised Good Psychiatric Practice guidance, and to express a commitment to the elimination of unlawful discrimination, the promotion of equality of opportunity and the promotion of good race relations. As part of the College's race relations strategy, and in accordance with the requirements of the Race Relations (Amendment) Act 2000 to promote equality of opportunity, all subscribing College Members and Fellows will now be able to put forward nominations for Fellowships, and not just two subscribing Fellows.

In the interests of equality of opportunity, College Officers are not required to be Fellows

Increasing use is being made of open appointments procedures, with vacancies being advertised in the Bulletin and on the website, and appointments to College Committees and some offices made by the CEC following interviews at the College. (The President, Dean, Librarian, Registrar and Treasurer will continue to be elected by ballot; Vice-Presidents, Editors, Associate Deans and Deputy Registrars will be appointed following advertisement and interview.)

\section{Trainees}

The register of Inceptors is replaced with a new category of association known as Pre-Membership Psychiatric Trainee for doctors in psychiatric training who have not yet passed the MRCPsych examination and are therefore not yet Members. A large percentage of doctors occupying psychiatric training posts have little or no contact with the College until they apply to take part I of the MRCPsych examination. Many were not aware of the Inceptor grade. Introducing a new grade with tangible benefits and support will provide a feeling of inclusion for trainees from their earliest moment in their chosen profession.

The Psychiatric Trainees' Committee replaces the Collegiate Trainees' Committee. The Committee will comprise 
both Pre-Membership and PostMembership Psychiatric Trainees.

columns

\section{Divisions}

A range of functions undertaken by the College centrally are being devolved to College Divisions; this will enhance the role of Divisions and enable Members to feel much more part of the College. Divi sions in Scotland, Ireland and Wales have had staffed offices for some time. These were introduced in response to political devolution. Staffed offices have now been introduced in Northern Ireland and in all the English Divisions. Divisions have been strengthened and will have the capacity to perform their enhanced role.

\section{Faculties}

The title of the Substance Misuse Faculty has been changed to the Faculty of
Addictions, a more inclusive term which reflects current terminology and encompasses addictive behaviour, such as gambling, as well as substance misuse.

Bye-Laws also now list the Faculties of Rehabilitation and Social Psychiatry, Liaison Psychiatry, and the new Faculty of Academic Psychiatry (introduced to provide a forum for debating issues specific to academic psychiatry and to ensure that the College is in a position to address the problems facing academic psychiatry).

\section{Retired Members}

There are a number of College Members who have retired and have chosen not to continue their registration with the General Medical Council. The College does not wish to lose contact with this group of senior Members, and amendment to the Bye-Laws now enables them to retain College Membership.

\section{Disciplinary procedures}

Procedures for the termination of Membership of or association with the College on disciplinary grounds have also been simplified. In future, authority for considering termination of Membership of or association with the College on these grounds will rest with the ETSC.

The College may now remove the Membership of any Member whose name has been erased from any register listed in section IX paragraph 1 (a). The Bye-Law also now states that consideration will be given to termination of Membership following conviction for a serious criminal offence.

The Bye-Laws and Regulations 2005 are available from the Book Sales Office (reference Occasional Paper OP61) and on the publications area of the College website at http://www.rcpsych.ac.uk/ publications/op/pdf/61.pdf 